\title{
Acidic Fibroblast Growth Factor Intracellular-Binding Protein
}

National Cancer Institute

\section{Source}

National Cancer Institute. Acidic Fibroblast Growth Factor Intracellular-Binding Protein. NCI Thesaurus. Code C26201.

Acidic fibroblast growth factor intracellular-binding protein (364 aa, $42 \mathrm{kDa}$ ) is encoded by the human FIBP gene. This protein may be involved in the regulation of the mitogenic activity of fibroblast growth factor 1 . 